\title{
THE VARYING RADIOCARBON ACTIVITY OF SOME RECENT SUBMERGED ESTONIAN PLANTS GROWN IN THE EARLY 1990s
}

\author{
Ingrid U Olsson \\ Department of Physics, Uppsala University, Box 530, SE-751 21 Uppsala, Sweden. Email: Ingrid_U.Olsson@Fysik.UU.SE. \\ Enn Kaup \\ Institute of Geology, Estonia Ave 7, 10143 Tallinn, Estonia
}

\begin{abstract}
Eleven samples of aquatic plants from three Estonian lakes were analyzed for their radiocarbon content in a collaboration between the laboratories in Tallinn and Uppsala. $\delta^{13} \mathrm{C}$ values for the actual species were compiled to allow normalization of activities measured in Tallinn without $\delta^{13} \mathrm{C}$ values. The range for well determined species is usually a few per mil and the statistical uncertainty $\geq 1 \%$ o. $\delta^{13} \mathrm{C}$ values vary considerably for different Potamogéton species and Myriophýllum spp. Lake Äntu Sinijärv and Lake Päidre are hard-water lakes containing 300 and $200 \mathrm{mg} \mathrm{HCO}_{3}{ }^{-} / \mathrm{L}$, respectively. One sample consisted of a carbonate crust deposited on a Ceratophýllum demersum plant in L. Äntu Sinijärv. Its $\Delta^{14} \mathrm{C}$ value was -147.3 $\pm 6.7 \%$ in 1990 , whereas the plant had a value of $-74.1 \pm 8.0 \%$ o $\left(\delta^{13} \mathrm{C}=-35.0 \%\right.$ o . The same species in L. Päidre had a $\Delta^{14} \mathrm{C}$ value of $+8.0 \pm 8.8 \%$ o $\left(\delta^{13} \mathrm{C}=-25.2 \%\right.$ ) in 1992 . Other species in $\mathrm{L}$. Päidre contained more ${ }^{14} \mathrm{C}$, from a $\Delta^{14} \mathrm{C}$ value of about $+30 \%$ o to about $+155 \%$, the latter value measured in Tallinn on floating leaves of Nuphar lútea, close to that of the contemporaneous atmospheric $\mathrm{CO}_{2}$. In the third lake, Lake Punso, containing $\leq 30 \mathrm{mg} \mathrm{HCO}_{3}-/ \mathrm{L}$, the stems of Nuphar lútea exhibited in 1990 a memory effect: the activity, $\Delta^{14} \mathrm{C}=209.6 \pm 10.3 \%$, significantly exceeded that of the contemporaneous atmospheric $\mathrm{CO}_{2}$. However, the floating leaves of the same plant had the $\Delta^{14} \mathrm{C}$ value $143.1 \pm 10.0 \%$, close to the atmospheric ${ }^{14} \mathrm{C}$ level in 1990. The memory is explained by nutrients stored in the root stock, used when the growth starts.
\end{abstract}

\section{INTRODUCTION}

The aim of this investigation was to study recent submerged plants in order to estimate the risk of obtaining too old radiocarbon ages on lake sediments. Nevertheless it has long been known, as summarized below, that the ${ }^{14} \mathrm{C}$ content of recent submerged plants does not provide a direct measure of the reservoir age. This study is part of an extensive investigation intended to elucidate one possible source of error in sediment dating. It is based chiefly on results from several Swedish lakes. Raivo Rajamäe initiated the present study in Estonia, but because he left the ${ }^{14} \mathrm{C}$ laboratory in Tallinn, the second author assumed responsibility for the descriptions and interpretations. Since very few samples were collected for this project some results from lakes in other countries had to be summarized for the interpretation.

Concern regarding ${ }^{14} \mathrm{C}$ dates on lake sediments was expressed already a few years after the ${ }^{14} \mathrm{C}$ method was devised. Iversen (personal communication with Deevey, 5 October 1949) warned that aquatic plants could be expected to be depleted in ${ }^{14} \mathrm{C}$, as compared with terrestrial plants, in consequence of their use of bicarbonate from ancient limestone.

Bartlett (1951) briefly discussed the datability of various materials. He mentioned that carbonate could be deposited in and on such plants as Potamogéton, Carex, and algae. These plants would also give rise to sediments deficient in ${ }^{14} \mathrm{C}$. He observed that e.g. roots may be rotten and yield humified material that may be extracted by a hydroxide solution and recommended treatment with acid to remove carbonates. He also referred to bioturbation, holes filled with younger material, intrusions, and benefits from mechanical pretreatment.

Godwin (1951) summarized some difficulties, inter alia that bicarbonate in lakes can cause ${ }^{14} \mathrm{C}$ ages to be too old, that e.g. bacterial activity can lead to too young an age, and that drainage channels may carry collodial material of various ages.

(C) 2001 by the Arizona Board of Regents on behalf of the University of Arizona

RadiocarBon, Vol 43, Nr 2B, 2001, p 809-820

Proceedings of the 17 th International ${ }^{14} \mathrm{C}$ Conference, edited by I Carmi and E Boaretto 
Westermark (1953) proved to be well aware of many possible sources of error. He, e.g., discussed the isotopic fractionation of carbon in the atmospheric carbon dioxide resulting in about $3 \%$ heavier ${ }^{13} \mathrm{C}$ and consequently about $6 \%$ heavier ${ }^{14} \mathrm{C}$ in carbonate than in biological carbon. He foresaw that corrections for this would be regarded necessary.

Deevey et al. (1954) discussed the hard-water problem and remarked that the assumption of isotopic equilibrium between the atmospheric $\mathrm{CO}_{2}$ and materials as carbonates and plants in hard waters may be false. Some of the reactions involved are not instantaneous. Collodial carbonates are also present. About 30 results are included. Most of them come from a lake, without inlet, receiving its water by seepage through limestone. Various samples, e.g. plants and shells with carbon deriving from the hard water, show a deficiency in ${ }^{14} \mathrm{C}$ relative to emergent plants, to some soft-water submerged plants and to some modern wood. Since no ${ }^{13} \mathrm{C}$ was measured, and thus no ${ }^{13} \mathrm{C}$ normalization performed, the slightly different results for samples using the atmospheric $\mathrm{CO}_{2}$ cannot be further discussed here. Deevey et al. were confident that Potamogéton plants use the bicarbonate in the lake water.

Oana and Deevey (1960) depicted the carbon cycle in a dimictic lake (overturning twice a year) to explain typical $\delta^{13} \mathrm{C}$ values. They based their discussion on $\delta^{13} \mathrm{C}$ values for Linsley Pond described as intermediate in hardness. Although the atmospheric $\mathrm{CO}_{2}$ has a $\delta^{13} \mathrm{C}$ value of $-7 \%$ and the plankton and the mud about $-30 \%$, the $\mathrm{CO}_{2}$ released from the bottom will rather have a value of about $-5 \%$, since methane with a value of about $-77 \%$ is produced concomitantly at the fermentation (Oana and Deevey 1960:Figure 1). Part of this methane and the carbon dioxide will disappear in bubbles, but the latter may also be dissolved as is that from the atmosphere with a slight fractionation. The authors also include a possible dissolution of carbonate and then obtain a value of about $-12 \%$ or dissolved $\mathrm{CO}_{2}$ and bicarbonate. In soft-water lakes the resulting carbon dioxide may be around $10 \%$ more depleted in ${ }^{13} \mathrm{C}$. More results are given by Stuiver and Deevey $(1961,1962)$ in lists. Several $\delta^{13} \mathrm{C}$ values of plant samples given by Oana and Deevey (1960) do not agree with those, for the same samples, published in lists by Stuiver and Deevey $(1961,1962)$. The results were also discussed by Stuiver (1975).

The early results and discussions should not be forgotten since they give an understandable preamble to later research at the same time as some early conclusions have to be questioned and even drastically changed. It seems that too little interest has been paid, in discussions of $\delta^{13} \mathrm{C}$, to what is already known about the source of carbon for different species of submerged plants.

In the 1960s the senior author started to separate two fractions of sediment by a simple $\mathrm{NaOH}$ treatment (Hörnsten and Olsson 1964) to obtain a soluble and an insoluble fraction, called (SOL) and (INS) respectively. Lipid extraction, separation according to size and weight etc. have since been tested. Some problems with decayed roots and rootlets were discussed by e.g. Olsson and Florin (1980:301). A lower carbon yield for roots than for the matrix of peat and gyttja has also been observed (Olsson 1991a:30).

To explain some odd results from Öland, a calcareous area, submerged and floating plants from 1966 and 1968 were examined for their deficiency relative to the contemporaneous atmosphere (Olsson et al. 1969; Olsson 1983). Submerged plants in a calcareous area were shown to yield different activity values in the same lake. Floating plants also showed a significant depletion and even emergent plants seemed to have lower ${ }^{14} \mathrm{C}$ activity than the atmosphere (Olsson 1983:Figure 2). Håkansson (1979) reported ${ }^{14} \mathrm{C}$ deficiencies of submerged plants, relative to the contemporaneous atmosphere from eight lakes with more or less calcareous surroundings. During the last two decades many more results have been published. 
The ${ }^{14} \mathrm{C}$ activity of the water and submerged plants in a lake is a complex function of the slow exchange of $\mathrm{CO}_{2}$ between the atmosphere and the water, the supply of old groundwater, the release of $\mathrm{CO}_{2}$ from the sediment, the consumption of $\mathrm{CO}_{2}$ in plant synthesis and the amount of dissolved carbonate.

\section{SITES, SAMPLES, TREATMENT, AND MEASUREMENTS}

The samples were collected from the middle of three lakes, where cores for pollen analysis were taken and dated in Tartu or Tallinn. Lake Äntu Sinijärv (Saarse and Liiva 1995) is a small alkaline lake in a group of three that are interconnected and fed by spring waters, in the karst area of Pandivere Upland $\left(59^{\circ} 08^{\prime} \mathrm{N}, 26^{\circ} 33^{\prime} \mathrm{E}\right)$. Its area is 2.4 ha and its maximum depth $7.3 \mathrm{~m}$. The sample was collected in June 1990, where the depth is $4 \mathrm{~m}$. The $\mathrm{HCO}_{3}{ }^{-}$is about $300 \mathrm{mg} / \mathrm{L}$. The top sediment is given as lacustrine lime. L. Päidre (Saarse et al. 1995) is a small lake in the hilly moraine area of Sakala Upland $\left(58^{\circ} 16^{\prime} \mathrm{N}, 25^{\circ} 30^{\prime} \mathrm{E}\right)$. Its area is 32.8 ha and its maximum depth $3.6 \mathrm{~m}$. The catchment area has been cultivated since it was drained in the 1980s. The samples were collected in August 1992, where the water depth is $1.2 \mathrm{~m}$. The $\mathrm{HCO}_{3}{ }^{-}$is about $200 \mathrm{mg} / \mathrm{L}$. The top sediment contains about $65 \%$ organic matter. L. Punso (Saarse and Rajamäe 1997) is a small lake in the immediate vicinity of L. Kirikumäe in the southeastern part of the Haanja Heights in a hilly area characterized by dead-ice topography $\left(57^{\circ} 40^{\prime} \mathrm{N}, 27^{\circ} 15^{\prime} \mathrm{E}\right)$. Its area is 3.2 ha and its depth less than $2 \mathrm{~m}$. The samples were collected in June 1990, where the water depth is $1.3 \mathrm{~m}$. The $\mathrm{HCO}_{3}{ }^{-}$is $\leq 30 \mathrm{mg} / \mathrm{L}$. The top sediment is a gyttja with high organic content. Samples and results from a fourth lake, L. Kahala (Rajamäe et al. 1997) in the Lahemaa National Park, $2 \mathrm{~km}$ north of the motorway Tallinn-Narva $\left(59^{\circ} 29^{\prime} \mathrm{N}, 25^{\circ} 31^{\prime} \mathrm{E}\right)$ are included in the discussions since two samples were collected-in 1994 and 1995, respectively. The lake is 350 ha in area and the maximum water depth $2.2 \mathrm{~m}$. The $\mathrm{HCO}_{3}{ }^{-}$is about $120 \mathrm{mg} / \mathrm{L}$. The top sediment has about $70 \%$ organic matter and the upper $60 \mathrm{~cm}$, a coarse detritus gyttja, contain macrofossils such as Potamogéton spp., Myriophýllum spicátum, Zannichéllia palustris and Najas fléxilis.

The investigated macrophytes are named and briefly described here according to Lid (1979). All the plants in this investigation are perennial, but if only the fresh growth is collected this does not constitute a problem. While Potamogéton natans L. has floating leaves, P. perfoliátus has not. Myriophýllum spp. have submerged leaves but the inflorescence protrudes above the water surface. Ceratophýllum demérsum L. has no roots and floats freely under water and can grow in fresh or brackish water. Nuphar lútea (L.) Sibth. et Sm. is rooted in the bottom, has a thick root stock and sends up stems with submerged leaves that finally float on the water surface. The stems and leaves are from the same specimen.

All the plants, except for the Ceratophýllum demérsum from L. Äntu Sinijärv, were pretreated by Rajamäe with $\mathrm{HCl}$, dried and stored. Some of the samples were too small to be measured with any accuracy in Tallinn but could be measured in Uppsala. Before combustion in Uppsala in 1993 or 1994 they were left to soak, slightly acidified with $\mathrm{HCl}$ - to ensure that any adsorbed carbon dioxide was removed-and dried again. One of these samples had to be diluted before the activity was measured. The original dry weight of the $C$. demérsum sample from L. Äntu Sinijärv was almost five times that from L. Päidre, so it was decided to test also the carbonate crust. The carbon yield of the organic fraction was smaller than that from the inorganic fraction, although both fractions were sufficient for normal measurements. The $C$. $d$. from L. Päidre had to be measured at slightly too low a pressure, instead of being diluted, but since all measurements on Estonian samples in Uppsala were recalculated using the revised standard values for the proportional counter (Olsson 1998), this did not constitute a problem. All uncertainties at the measurement were considered. The Tallinn values 
for the three originally studied lakes, after measurements with a scintillation counter, were not $\delta^{13} \mathrm{C}$ normalized, so a study of stable isotopes of aquatic plants had to be performed to allow reasonable assumptions. The original sigma-value was based on counting statistics only. The results are given in Table 2 including 2 later measurements, both $\delta^{13} \mathrm{C}$ normalized, completed in Tallinn by Rajamäe.

\section{AQUATIC PLANTS AND $\delta^{13} \mathrm{C}$}

Because of the wide range for $\delta^{13} \mathrm{C}$ it is essential to include $\delta^{13} \mathrm{C}$ normalizations. The isotopic fractionation for $\mathrm{CO}_{2}(\mathrm{~g})$ in equilibrium with bicarbonate is slightly temperature dependent. The gas is about $7 \%$ lighter at $30{ }^{\circ} \mathrm{C}$ and $11 \%$ at $0{ }^{\circ} \mathrm{C}$. The dissolved gas, $\mathrm{CO}_{2}(\mathrm{aq})$, is about $1 \%$ o lighter than $\mathrm{CO}_{2}(\mathrm{~g}) . \mathrm{CaCO}_{3}$ is slightly heavier than $\mathrm{HCO}_{3}{ }^{-}$when precipitated at temperatures above $+10^{\circ} \mathrm{C}$, but lighter at lower temperatures. The $\mathrm{CO}_{3}=$ ion is about $3.5 \%$ o lighter than the $\mathrm{CaCO}_{3}$. The amount of dissolved $\mathrm{CO}_{2}$ is very small at a $\mathrm{pH}$ of about 8.5 where the bicarbonate has its maximum. The amounts are $50 \%$ of the total carbon for both at $\mathrm{pH}$ about 6.5 . Kinetic processes play an important role in the photosynthesis. The aquatic plants can use bicarbonate and/or carbon dioxide. The $\delta^{13} \mathrm{C}$ value of a plant always reflects that of the source. Terrestrial or aquatic environment, light, $\mathrm{pH}$, temperature, salinity and availability of the carbon sources, the physiology of the plants with their lacunal system (air chambers) are factors to be considered. The $\delta^{13} \mathrm{C}$ range is wide-about $25 \%$ for plants used in Uppsala for studies like this.

Terrestrial plants are characterized according to the different photosynthetic pathways involved: $\mathrm{C}_{3}$, $\mathrm{C}_{4}$ and CAM plants with $\delta^{13} \mathrm{C}$ ranges about -22 to $-34 \%$ and -8 to $-20 \%$ or the first two, respectively, and a wide range of values for the CAM plants, indicating that the two fixation processes for $\mathrm{C}_{3}$ and $\mathrm{C}_{4}$ plants are involved. In the early $1980 \mathrm{~s}$, several aquatic macrophytes were found to use CAM photosynthesis (Keeley et al. 1986). Some $\delta^{13} \mathrm{C}$ ranges for aquatic plants are given in Table 1 as an illustration of the problems encountered in this study and as a basis, together with the survey above, for the choice of assumed values, if $\delta^{13} \mathrm{C}$ measurements are lacking. The uncertainty of an assumed $\delta^{13} \mathrm{C}$ value must be greater for Potamogéton natans than for $P$. perfoliátus, since the latter has no floating leaves.

An obvious source of differences is that some aquatic plants have floating leaves but others, of the same genus, do not. Potamogéton is an example of this. Myriophýllum spp. have submerged leaves but the inflorescence project above the surface. Some species of a genus, e.g. Carex, grow either on land or in water. A general conclusion such as "the organic carbon of submerged aquatics (Myriophýllum, Nitella, Potamogéton, Chara) is enriched in proportion to the hardness of the water" (Oana and Deevey 1960:263) is thus probably not valid since further information is needed. Similarly, other statements based on statistical analyses, disregarding which species and what aquatic milieu have been involved, may be false.

Steemann Nielsen (1946) described an experiment with Myriophýllum spicátum showing that this species could assimilate not only free $\mathrm{CO}_{2}$ but also $\mathrm{HCO}_{3}{ }^{-}$to the extent that the plant could maintain the assimilation in $\mathrm{CO}_{2}$-poor water. The rate in the latter case was also dependent on the ions present in the solution. A similar experiment with the moss Fontinalis anttipyretica indicated so low a rate when using $\mathrm{HCO}_{3}{ }^{-}$that the carbon fixation is dependent on $\mathrm{CO}_{2}$ in the water.

Scientists at the Freshwater Biological Laboratory, University of Copenhagen have studied Isoetid species (Wium-Andersen 1971; Wium-Andersen and Andersen 1972; Søndergaard and Sand-Jensen 1979; Sand-Jensen and Prahl 1982). Keeley et al. (1986) report that CAM activity could be associated with the water milieu but was lost under aerial conditions in some species. Lobélia, Isóetes, and Littorélla are able to absorb $\mathrm{CO}_{2}$ through their roots, which are extensive. The interstitial $\mathrm{CO}_{2}$ in the sed- 
iment often reaches a value 100 times that dissolved in the lake water, around the leaves. The final diffusion is determined by the concentration gradient between the gas-filled lacunae in the leaves and the surrounding water. Stirring improved the conditions. Because of this pumping effect and the release of oxygen in the sediment the Isoetid species affect the environment and the aerobic activity in the sediment. Diffusional resistances seem to play an important role for the carbon fixation. Keeley et al. (1986) state that plants with different photosynthetic pathways may have similar $\delta^{13} \mathrm{C}$ values, but that distinctly different $\delta^{13} \mathrm{C}$ values can be seen for plants with similar photosynthetic pathways.

Table 1 Some $\delta^{13} \mathrm{C}$ values for selected aquatic plants and for mixed samples from a lake or region

\begin{tabular}{|c|c|c|c|}
\hline Species & Lake (and remarks) & $\delta^{13} \mathrm{C} \%$ & Reference \\
\hline Carex rostrata Stokes & Säynäjälampi (shore) & -28.4 & Olsson et al. (1983) \\
\hline Carex elata & Vån (terrestrial) & -27.4 & Håkansson (1979) \\
\hline Carex spp. & $\begin{array}{l}4 \text { lakes in S. Sweden } \\
\text { (terrestrial). (6 samples) }\end{array}$ & $-25.7--29.4$ & Håkansson $(1977,1979,987)$ \\
\hline Potamogéton spp. & $\begin{array}{l}3 \text { lakes, various degrees of } \\
\text { hardness ( } 9 \text { samples) }\end{array}$ & $-12.6--20.6$ & Stuiver and Deevey $(1961,1962)$ \\
\hline Potamogéton natans & $\begin{array}{l}2 \text { lakes, Uppland, Sweden } \\
\text { (4 samples) }\end{array}$ & $-27.4--28.4$ & Olsson (forthcoming) \\
\hline Potamogéton perfoliátus & $\begin{array}{l}3 \text { lakes, Uppland, Sweden } \\
\text { (3 samples) }\end{array}$ & $-19.6--22.3$ & Olsson (forthcoming) \\
\hline Potamogéton perfoliátus & $\begin{array}{l}\text { Ämmern, S. Sweden } \\
\text { (calcareous) }\end{array}$ & -17.4 & Håkansson (1977) \\
\hline Potamogéton lucens & $\begin{array}{l}2 \text { lakes, Uppland, Sweden } \\
\text { (2 samples) }\end{array}$ & $-17.4--18.5$ & Olsson (forthcoming) \\
\hline Potamogéton spp. & $\begin{array}{l}3 \text { lakes, various degrees of } \\
\text { hardness ( } 9 \text { samples) }\end{array}$ & $-12.6--20.6$ & Stuiver and Deevey $(1961,1962)$ \\
\hline Potamogéton spp. ${ }^{\mathrm{a}}$ & Säynäjälampi & -25.1 & Donner et al. (1971) \\
\hline Potamogéton spp. ${ }^{\mathrm{a}}$ & Säynäjälampi & -23.1 & Olsson et al. (1983) \\
\hline Potamogéton compressus $\mathrm{L}$. & Säynäjälampi & -27.6 & Olsson and Vasari (1996) \\
\hline Potamogéton alpínus Balbis & $\begin{array}{l}\text { Säynäjälampi } \\
\text { (SOL fraction) }\end{array}$ & -30.1 & Olsson and Vasari (1996) \\
\hline Mixture including moss ${ }^{\mathrm{a}}$ & Säynäjälampi & -33.1 & Olsson et al. (1983) \\
\hline Myriophyllum spp. & $\begin{array}{l}\text { Quassapaug } \\
\text { (very soft water) }\end{array}$ & -27.4 & Stuiver and Deevey (1961) \\
\hline Myriophyllum spp. & $\begin{array}{l}\text { Wononscopomuc } \\
\text { (hard water) }\end{array}$ & -11.2 & Stuiver and Deevey (1962) \\
\hline $\begin{array}{l}\text { Myriophyllum, mostly } \\
\text { spicátum }\end{array}$ & $\begin{array}{l}\text { Tarmlången, Uppland, } \\
\text { Sweden (6 samples) }\end{array}$ & $-17.4--19.5$ & Olsson (forthcoming) \\
\hline Myriophyllum spicátum & $\begin{array}{l}\text { Striern } \\
\text { (calcareous) S. Sweden } \\
\text { (2 samples) }\end{array}$ & $-19.8--20.0$ & Håkansson (1977) \\
\hline $\begin{array}{l}\text { Myriophyllum, mostly verti- } \\
\text { cillátum or alterníflorum }\end{array}$ & $\begin{array}{l}\text { Siggeforasjön, Uppland, } \\
\text { Sweden ( } 5 \text { samples) }\end{array}$ & $-18.9--22.8$ & Olsson (forthcoming) \\
\hline Myriophyllum alterníflorum & $\begin{array}{l}\text { Hinnasjön (non-calcareous) } \\
\text { S. Sweden }\end{array}$ & -24.3 & Håkansson (1977) \\
\hline Myriophyllum alterníflorum & $\begin{array}{l}\text { Odensjön (non-calcareous) } \\
\text { S. Sweden (3 samples) }\end{array}$ & $-18.7--20.4$ & Håkansson $(1977,1987)$ \\
\hline
\end{tabular}

${ }^{a}$ Species listed in original papers and by Olsson and Vasari (1996)

Deuser et al. (1968) presented a model for a decreased fractionation in marine plankton because of limited availability. Whereas the normal shift in $\delta^{13} \mathrm{C}$ is -18 to $-19 \%$ from bicarbonate to the cell, it will be less when the source is too small to be regarded as essentially constant. The cell simply has to accept heavier carbon. This is possible to a certain extent. The effect is more severe at higher tem- 
peratures since then the growth rate is higher and the available carbon is diminished. Thus isotopically lighter plankton may be more common in cold than in warm waters.

It is difficult to use $\delta^{13} \mathrm{C}$ values for determination of the origin of sediments, deriving not only from macrophytes discussed here, but also from aquatic mosses and algae, since the $\delta^{13} \mathrm{C}$ values for aquatics have a range over $30 \%$.

\section{VALUES FOR CONTEMPORANEOUS ATMOSPHERIC ${ }^{14} \mathrm{C}$ ACTIVITY}

This investigation deals with samples from 1990 and later, but we know very little about the contemporaneous atmospheric activity in Estonia for the actual years. Ilves (in preparation) presented a poster at the ${ }^{14} \mathrm{C}$ conference in Groningen 1997 depicting the activities of Estonian tree rings from 1924 to 1990 . The $\Delta^{14} \mathrm{C}$ maximum was $900 \pm 10 \%$ in 1964 (misprinted as 990 in the abstract book) and the activity was given as $738 \pm 9 \%$ in 1963 . Considering the time for growth, these values should be compared to the four values given for each of the two years by Olsson and Possnert (1992: Figures 3, 4; Table 1) on early and late wood for cellulose and insoluble fractions. The Uppsala values never reached the Estonian maximum value and were higher for 1964 than for 1963. For 1990, Ilves' value was $150 \pm 4 \%$ o. At that time the decrease of the $\Delta^{14} \mathrm{C}$ for the atmospheric carbon dioxide from one year to the next was small but significant and seasonal variations occurred. The trend for the $\Delta^{14} \mathrm{C}$ values for atmospheric carbon dioxide for the 1960s and the late 1970s are given by Olsson (1983:Figures 2,3). Håkansson (1979:Figure 1) depicted the activity for some terrestrial plants from 1974 and 1975. Olsson (1993) discussed a higher activity at Abisko in northern Sweden than over Svalbard and concluded (Olsson 1999) that the difference varied but still existed in 1995 and had been about 1\% since the 1960s. Olsson (1993:Figure 1) described the decrease during the 1980s as irregular and reported a sudden increase in Sweden in 1992 (Olsson 1999:105). The values in Central Europe indicate an industrial effect-lower activities than those from northern Sweden and the environs of Uppsala. It seems most appropriate to use only Estonian values for this study. Ilves also presented some values from other objects from 1990 and 1991, yielding values from 145\%o to $162 \%$. The lowest value referred to pine shoot needles and the highest to human blood. For the latter the activity should be higher than for the wood, since blood is affected by a memory effect. The food consumed should partly derive from earlier years and the blood itself exhibits some delay. A high proportion of fish in the diet would be reflected as a reservoir effect. Unfortunately, Ilves had no possibility to measure $\delta^{13} \mathrm{C}$ for his samples. Thus, considering the delay and an estimated ${ }^{13} \mathrm{C}$ normalization, the ${ }^{14} \mathrm{C}$ activity excess of the atmosphere for Estonia in 1990 is close to a value between $140 \%$ and $155 \%$ according to Ilves' measurements.

Rajamäe (personal communication) measured three samples from 1990. Two of them were collected in southeastern Estonia. After $\delta^{13} \mathrm{C}$ normalization, using the assumed values $-27.0 \%$ and $-12.0 \%$ respectively, they yield $\Delta^{14} \mathrm{C}$ values: $171.1 \pm 5.6 \%$, Tln-1613, birch leaves from June 1 and $157.9 \pm$ 7.2\%o, Tln-1612, maize from August 1. The third sample, birch leaves, was collected from the Kurtna kame field in northeastern Estonia. With the assumed $\delta^{13} \mathrm{C}$ value $-27.0 \%$ o the excess is 163.2 $\pm 3.3 \%$ o, Tln-1494. Rajamäe measured still one sample from southeastern Estonia, maize from 31 July 1979 , Tln- 450 . It yielded a $\Delta^{14} \mathrm{C}$ value of $335.4 \pm 9.4 \%$ ofter $\delta^{13} \mathrm{C}$ normalization using the assumed value $-12.0 \%$.

The Estonian values for the recent ${ }^{14} \mathrm{C}$ activity of the atmospheric carbon dioxide are too few and scattered for definite conclusions about the actual level, which may be different from that for other areas in northern Europe. The uncertainty in the activity level is of virtually no importance for the main conclusions drawn in this study. 


\section{RESULTS AND DISCUSSION}

The results are given in Table 2. Four samples of water plants collected in 1990 in L. Punso yielded four different activity values. Two were determined in Uppsala on Nuphar lútea, viz. leaves and stems respectively from the same plant. The stem was seen to have a higher ${ }^{14} \mathrm{C}$ activity than the leaves. The nutrients stored in the root stock during a season will only partly be used in a later season. The nutrients in the root stock should thus be expected to depend on the atmospheric activity some years earlier-to show a memory value. The plant activity should reflect a balance between that of stored nutrients and that of assimilated carbon dioxide. Since the atmospheric activity still was on a decreasing trend at the time for the growth, submerged parts from the early growth, the stems, should have a higher activity than the floating leaves. Similar results were obtained earlier on plants, collected in July and September 1980, and depicted in a preliminary figure by Olsson (1983). Nymphaéa alba leaves below the surface of L. Långa Getsjön had a slightly, but not significantly, higher ${ }^{14} \mathrm{C}$ activity than floating leaves. Emergent parts of Equisétum in the same lake were shown to have about the same activity as the $N$. $a$. plants although a somewhat lower activity than terrestrial plants from Smara, near to Uppsala. A Nymphaeáceae root stock from Gillfjärden, close to Uppsala, had a significantly higher activity than a submerged Potamogéton plant collected within the same small spot of the lake, but a somewhat lower activity than the Smara plants. Other water plants from Gillfjärden and some other lakes close to Uppsala, had varying activities as will be discussed and presented elsewhere in tables together with more data on the atmospheric activity. Olsson (1986:Figure 3) has an activity measurement on the submerged Ephydatia fluviatilis collected in 1981 in L. Långa Getsjön significantly below that of the contemporaneous Swedish atmosphere but significantly higher than that of three fractions, with very different activities, recovered from the lake water.

The Carex and the Potamogéton natans samples from Lake Punso, measured in Tallinn, were both measured without any $\delta^{13} \mathrm{C}$ normalization. The original internal difference is small-21.9 $\pm 8.4 \%$. When normalizing the values for ${ }^{13} \mathrm{C}$, using assumed values, the activities still appear rather close to —not significantly higher than - the atmospheric activity in Estonia as measured by Rajamäe. It should, however, be recalled that the three atmospheric-activity measurements (Rajamäe, personal communication) in Tallinn, for 1990 on birch leaves and maize yielded higher activity than that reported by Ilves. The activity value for 1979, Tln-450, is significantly lower than that given by Ilves for the same year.

The range for the three samples from 1990, as originally given by Rajamäe, was 30\%, but the differences in activity declined to non-significant values after a ${ }^{13} \mathrm{C}$ normalization at the same time as the uncertainties increased. The activity range for the three samples is indeed similar to that detected elsewhere although the total spread for Estonia, including the values given by Ilves, is alarming.

It seems that the present ${ }^{14} \mathrm{C}$ activity of dissolved carbon dioxide in L. Punso is about the same as that of the atmospheric carbon dioxide. It may be a local effect. A dense vegetation, if present, would have given a sediment with high activity affecting the balance between uptake of atmospheric carbon dioxide, the release of gas from the sediment and any other supply. Such a case was studied at L. Siggeforasjön (Olsson 1991a, 1991b; in preparation): Lobélia dortmánna, taking its carbon as $\mathrm{CO}_{2}$ from the sediment, had (in 1985, 1989, and 1990) a higher activity for plants from an area with dense reed vegetation than from a spot some hundred meters away where the bottom was sandy and the vegetation very sparse. In L. Siggeforasjön, a smaller activity decrease was also detected for some submerged plants than for the atmospheric carbon dioxide during a decade. 
Table 2 The activity excesses for aquatic plants from Estonia

\begin{tabular}{|c|c|c|c|c|c|c|c|c|c|}
\hline $\begin{array}{l}\text { Lake, } \\
\text { collection, } \\
\text { and } \\
\text { reference }\end{array}$ & $\begin{array}{l}\text { Bicarbonate } \\
\text { content, } \\
\text { water depth }\end{array}$ & $\begin{array}{l}\text { Species and parts } \\
\text { of plants }\end{array}$ & $\begin{array}{l}\text { Tallinn: } \\
\text { pMC }(9 \\
\text { modern }\end{array}$ & & $\begin{array}{l}\delta^{13} \mathrm{C} \\
\% o\end{array}$ & \pm & $\begin{array}{l}\Delta^{14} \mathrm{C} \\
\% o\end{array}$ & \pm & $\begin{array}{l}\text { Dating } \\
\text { number }\end{array}$ \\
\hline $\begin{array}{l}\text { L. Punso } \\
\text { S. Estonia } \\
\text { June } 1990\end{array}$ & $\begin{array}{l}\leq 30 \mathrm{mg} / \mathrm{L} \\
1.3 \mathrm{~m}\end{array}$ & Carex emerged & 115.95 & 0.56 & $\begin{array}{l}-27.0 \\
\text { (assur }\end{array}$ & $\begin{array}{l}3.0 \\
\text { led) }\end{array}$ & 164.1 & 9.0 & $\begin{array}{l}\text { Tln- } \\
1608\end{array}$ \\
\hline \multirow[t]{3}{*}{$\begin{array}{l}\text { Saarse and } \\
\text { Rajamäe } \\
1997\end{array}$} & & $\begin{array}{l}\text { Potamogéton na- } \\
\text { tans } \\
\text { leaves and stems }\end{array}$ & 118.14 & 0.60 & $\begin{array}{l}-27.0 \\
\text { (assun }\end{array}$ & $\begin{array}{l}5.0 \\
\text { eed) }\end{array}$ & 186.1 & 9.3 & $\begin{array}{l}\text { Tln- } \\
1601\end{array}$ \\
\hline & & $\begin{array}{l}\text { Nuphar lútea } \\
\text { leaves }\end{array}$ & & & -25.3 & 0.3 & 143.1 & 10.0 & U-4655 \\
\hline & & $\begin{array}{l}\text { Nuphar lútea } \\
\text { stems }\end{array}$ & & & -25.0 & 0.3 & 209.6 & 10.3 & U-4654 \\
\hline $\begin{array}{l}\text { L. Päidre } \\
\text { S. Estonia } \\
\text { August } \\
1992\end{array}$ & $\begin{array}{l}\text { c. } 200 \mathrm{mg} / \mathrm{L} \\
1.2 \mathrm{~m}\end{array}$ & $\begin{array}{l}\text { Potamogéton na- } \\
\text { tans } \\
\text { leaves and stems }\end{array}$ & 108.30 & 1.8 & $\begin{array}{l}-27.0 \\
\text { (assun }\end{array}$ & $\begin{array}{l}5.0 \\
\text { led) }\end{array}$ & 87.3 & 21.1 & $\begin{array}{l}\text { Tln- } \\
1729\end{array}$ \\
\hline \multirow{4}{*}{$\begin{array}{l}\text { Saarse et al. } \\
1995\end{array}$} & & P. perfoliátus & & & -22.2 & & 69.5 & 16.1 & U-4653 \\
\hline & & $\begin{array}{l}\text { Myriophyllum } \\
\text { spp. }\end{array}$ & 104.33 & 0.73 & $\begin{array}{l}-19.5 \\
\text { (assur }\end{array}$ & $\begin{array}{l}3.0 \\
\text { hed) }\end{array}$ & 31.8 & 9.6 & $\begin{array}{l}\text { Tln- } \\
1748\end{array}$ \\
\hline & & $\begin{array}{l}\text { Ceratophyllum } \\
\text { demérsum }\end{array}$ & & & -25.2 & 0.3 & 8.0 & 8.8 & U-4652 \\
\hline & & $\begin{array}{l}\text { Nuphar lútea } \\
\text { floating leaves }\end{array}$ & 115.42 & 0.72 & $\begin{array}{l}-25.0 \\
\text { (assur }\end{array}$ & $\begin{array}{c}2.0 \\
\text { hed) }\end{array}$ & 154.2 & 8.3 & $\begin{array}{l}\text { Tln- } \\
1724\end{array}$ \\
\hline $\begin{array}{l}\text { L. Äntu } \\
\text { Sinijärv } \\
\text { E. Estonia } \\
\text { June } 1990\end{array}$ & $\begin{array}{l}\text { c. } 300 \mathrm{mg} / \mathrm{L} \\
4 \mathrm{~m}\end{array}$ & $\begin{array}{l}\text { Ceratophyllum } \\
\text { demérsum } \\
\text { (organic fraction) }\end{array}$ & & & -35.0 & 0.3 & -74.1 & 8.0 & U-4651 \\
\hline $\begin{array}{l}\text { Saarse and } \\
\text { Liiva } 1995\end{array}$ & & $\begin{array}{l}\text { Ceratophyllum } \\
\text { demérsum } \\
\text { (carbonate crust) }\end{array}$ & & & -7.8 & 0.3 & $\begin{array}{c}-147.3 \\
6.7\end{array}$ & & $\mathrm{U}-4650$ \\
\hline $\begin{array}{l}\text { L. Kahala } \\
\text { N. Estonia } \\
1994\end{array}$ & $\begin{array}{l}\text { c. } 120 \mathrm{mg} / \mathrm{L} \\
\leq 2.2 \mathrm{~m}\end{array}$ & $\begin{array}{l}\text { Myriophyllum } \\
\text { spp. }\end{array}$ & 107.74 & 1.25 & -17.8 & 0.5 & $\begin{array}{l}77.4 \\
12.5\end{array}$ & & $\begin{array}{l}\text { Tln- } \\
1986\end{array}$ \\
\hline $\begin{array}{l}\text { L. Kahala } \\
\text { N.Estonia } \\
1995\end{array}$ & & $\begin{array}{l}\text { Myriophyllum } \\
\text { spp. }\end{array}$ & 110.94 & 0.68 & -12.2 & 0.5 & $\begin{array}{l}109.4 \\
6.8\end{array}$ & & $\begin{array}{l}\text { Tln- } \\
1987\end{array}$ \\
\hline $\begin{array}{l}\text { Rajamäe et } \\
\text { al. } 1997\end{array}$ & & & & & & & & & \\
\hline
\end{tabular}

The question is whether or not a top sediment, $10 \mathrm{~cm}$ thick of Lake Punso, indicates a possible deficiency in the ${ }^{14} \mathrm{C}$. Presumably it was deposited during several decades before 1990. Lake Kirikumäe, the lake nearby L. Punso, has a seasonal inflow from L. Punso. It is also low in $\mathrm{HCO}_{3}{ }^{-}$. The top layer there was determined, via ${ }^{210} \mathrm{~Pb}$, to have been deposited at a rate of less than about $0.2 \mathrm{~cm} / \mathrm{yr}$ (Rajamäe and Varvas 1990). In other words: a layer of sediment $10 \mathrm{~cm}$ thick would be deposited in more than about 50 years. Part of the topmost $10 \mathrm{~cm}$ must be affected by the atomic-bomb effect. Although the sediment accumulation rate in L. Punso differs from that in L. Kirikumäe, to judge from the ${ }^{14} \mathrm{C}$ ages, the influence of the atomic-bomb effect should be present at least in the topmost $10 \mathrm{~cm}$; in other words, the sediment age should appear smaller than it would without this activity contribution. Thus, the age $145 \pm 60{ }^{14} \mathrm{C}$ years (Saarse and Rajamäe 1997) cannot be used to indicate a negligible reservoir age. Calibration, for terrestrial samples with this ${ }^{14} \mathrm{C}$ age, would yield a wide range for the calibrated age. 
Donner et al. (1971) measured the ${ }^{14} \mathrm{C}$ activity of mud from the surface layer of the bottom mud of L. Säynäjälampi, a hard-water lake about 1-2 m deep. The delta value was $-123 \pm 14 \%$ in 1970 . A Potamogéton sample yielded the delta value $+159 \pm 13 \%$. At a new investigation (Olsson et al. 1983 ) the top sediment was sliced in thin layers. The topmost layer was apparently affected by erosion due to agriculture as a consequence of the post-war settlement. Fens in the vicinity were first drained in 1947-49. The organic content of the top layer was very low. The layer next to the top layer was dated at about 1700 years and the next four layers, down to about $5 \mathrm{~cm}$ depth in the sediment, as a mean slightly older than 2000 years. Different fractions from the pretreatment, yielding seven samples, were used. Submerged plants collected in 1978 had slightly varying activities but all three samples indicated delta values close to zero. In 1992, when the atmospheric activity had decreased further, the submerged plants had activities (Olsson and Vasari 1996) indicating a deficiency against the standard of around $6 \%$. This is equivalent to about $21 \%$ less than the contemporaneous atmosphere. A slow response to the decrease of the ${ }^{14} \mathrm{C}$ activity of the atmosphere is obvious.

Similar slicing of the top sediment in L. Långa Getsjön, a dystrophic lake for which the diatoms indicate that very little carbon dioxide may be dissolved, yielded samples from which Olsson and Florin (1980) could determine the reservoir age by an extrapolation to the sediment surface. This was estimated as a few hundred years in agreement with their value based on age determinations of a pollen stratigraphical level, the rational limit for Picea, in the lake and the nearby Långa Getsjöbog. Ingmar and Olsson (in preparation) also have examples of top sediments, 5-10 cm, sliced into several layers which never reach apparent ages younger than about -1100 years although the sediment further down indicated apparent ages of around 500 or 1000 years (Olsson 1972; 1991a). Many water plants from these hard-water lakes, studied by Ingmar and Olsson, have been measured.

Erosion because of agriculture activities, known by historical records or by pollen analysis, and water-level changes are two reasons for too old ${ }^{14} \mathrm{C}$ dates of a sediment layer. The topmost layer of a sediment is often affected by the atomic-bomb tests and yields too young a ${ }^{14} \mathrm{C}$ age. It is risky to use the topmost layer for discussions of reservoir ages.

L. Päidre yields an example of varying activities among the aquatic plants in a lake. The Nuphar lútea floating leaves can, according to the discussion above, have an activity close to that of the atmosphere. The deviation is determined by the balance between two factors-higher activity because of a memory effect (nutrients in the root stock - the contribution will depend on the age of the particular plant), and lower because of the assimilation below the water surface. Similarly $P$. natans has poorly defined supply of carbon dioxide. Both $P$. perfoliátus and Ceratophýllum demérsum are good indicators of an existing reservoir effect.

Only two results came from L. Äntu Sinijärv, both with an appreciable reservoir age of the water. Since the collected plant, Ceratophýllum demérsum, has no roots and exhibits the lowest activities in the lakes, a question arises regarding the assimilation pathways.

The sample from L. Kahala collected in 1994 has a lower atmospheric activity than that expected from Swedish values. The sample collected in 1995, with about 32\%o higher activity than that from 1994 (about $2 \sigma$ for the difference), has an activity close to the activity in Abisko, northern Sweden.

Bergquist (1964) studied the net increase of growth, the dry weight, after fertilizing with $\mathrm{CO}_{2}$ in hydrocultures. He inferred that there is a possibility of a small uptake by plant roots, but refrained from any definite conclusion. He used beans, tomatoes, and mustard. Olsson et al. (1972) and Olsson $(1972,1979)$ reported an experiment with tomatoes grown outdoors in buckets and fed with carbonates rich in, or devoid of, ${ }^{14} \mathrm{C}$. Too few results were obtained for definite conclusions, but also 
these experiments implied some uptake by roots. If so, this may explain the activity differences between the rooted plants and the freely floating submerged plants. The vegetation density in the actual spot of the lake then plays an important role.

\section{CONCLUSIONS}

Extrapolation of sediment layers to the sediment surface may give an idea whether there is a reservoir age. The method has been used with success earlier, but cannot reveal the conditions long ago. The reliability of dates can also be discussed from results on different grain sizes or from chemical fractions. The influence of graphite may thus be eliminated by a simple $\mathrm{NaOH}$ extraction leaving insoluble material. Some fractionation at combustion was tested in Uppsala already in the seventies and recently refined in another laboratory. Water level changes easily lead to erosion. Agricultural activities can enhance the influx of contaminants. Humic acid from adjacent bogs can contribute dissolved organic material. Aged water from wells is always a factor to consider. The age of a sediment is also affected by the supply of terrestrial material and by the relative contribution of emergent or partly floating plants. The apparent age of a sediment, as caused by various factors, is thus expected to vary with the location on the bottom of a lake and with time. Careful analyses of ${ }^{14} \mathrm{C}$ for certain well determined pollen-analytical levels in a lake and an adjacent bog can provide information about the variation with time.

It is stressed that the top sediment, when partly or totally deposited after 1955 will be affected by the atomic-bomb tests. Such a layer must be excluded in an extrapolation to the surface. The difference in activity between the atmospheric carbon dioxide and that in aquatics can vary according to other circumstances than the hardness of the water. Some large differences seem to decrease with time, indicating a slow response. The various species in a lake may have different activities even if they are classified as submerged, as seen from the present investigation as well as from earlier ones.

The investigated aquatic samples, when really submerged, provide evidence of a reservoir effect. No really submerged plant was sampled from L. Punso. The upper sediment layers, disregarding the top layer affected by the atmospheric activity increase due to atomic-bomb tests, also indicate an apparent age for all lakes in this investigation.

\section{ACKNOWLEDGMENTS}

We are grateful to Raivo Rajamäe for his introductory work on the collection and preparation of the aquatic samples, for the measurements which he made in Tallinn and for allowing us to use all his results and available information about the samples. Moreover we thank Evald Ilves for sending us his manuscript and permitting us to use the data therein and also further data, related to his study. Tomas Kronberg is acknowledged for his ${ }^{13} \mathrm{C}$ measurements when working in the AMS laboratory. Financial support was given by the Swedish Natural Science Research Council, not only for Rajamäe's stay in Uppsala but also to the senior author, and by the Estonian basic research funding No $0330357 \mathrm{~s} 98$ to the junior author and for the cost of the measurements completed in Tallinn. We also express our thanks to the heads of our respective Departments allowing us to make this summary.

\section{REFERENCES}

Bartlett HH. 1951. Radiocarbon datability of peat, marl, caliche, and archaeological materials. Science 114: $55-6$.
Bergquist NO. 1964. Absorption of carbon dioxide by plant roots. Botaniska Notiser 117(Fasc.3):249-61.

Deevey ES Jr, Gross MS, Hutchinson GE, Kraybill HL. 
1954. The natural $\mathrm{C}^{14}$ contents of materials from hardwater lakes. Proceedings National Academy of Sciences of the United States of America, Washington 40: $285-8$.

Deuser WG, Degens ET, Guillard RRL. 1968. Carbon isotope relationships between plankton and sea water. Geochimica et Cosmochimica Acta 32:657-60.

Donner JJ, Jungner H, Vasari Y. 1971. The hard-water effect on radiocarbon measurements of samples from Säynäjälampi, norh-east Finland. Commentationes Physico-Mathematicae 41:307-10.

Godwin H. 1951. Comments on radiocarbon dating for samples from the British Isles. American Journal of Science 249:301-7.

Håkansson S. 1977. University of Lund radiocarbon dates X. Radiocarbon 19(3):424-41.

Håkansson S. 1979. Radiocarbon activity in submerged plants from various south Swedish lakes. In: Berger R, Suess HE, editors. Radiocarbon dating (Proceedings of the 9th International Conference). University of California Press. p 433-43.

Håkansson S. 1987. University of Lund radiocarbon dates XX. Radiocarbon 29(3):353-79.

Hörnsten Å, Olsson IU. 1964. En C ${ }^{14}$-datering av glaciallera från Lugnvik, Ångermanland. Geologiska Föreningens i Stockholm Förhandlingar 86:206-10.

Keeley JE, Sternberg LO, DeNiro MJ. 1986. The use of stable isotopes in the study of photosynthesis in freshwater plants. Aquatic Botany 26:213-23.

Lid J. 1979. Norsk og Svensk Flora. Oslo: Det Norske Samlaget. 808 p.

Oana S, Deevey ES. 1960. Carbon 13 in lake waters, and its possible bearing on paleolimnology. American Journal of Science 258-A:253-72.

Olsson IU. 1972. The pretreatment of samples and the interpretation of the results of ${ }^{14} \mathrm{C}$ determinations. In: Vasari Y, Hyvärinen H, Hicks S, editors. Climatic changes in Arctic areas during the last ten-thousand years (Proceedings A symposium at Oulanka and Kevo, 1971) Acta Universitatis Ouluensis Ser A 3 Geologica 1:9-37.

Olsson IU. 1979. The radiocarbon contents of various reservoirs. In: Berger R, Suess HE, editors. Radiocarbon dating (Proceedings of the 9th International Conference). University of California Press. p 613-18.

Olsson IU. 1983. Dating non-terrestrial materials. PACT 8:277-94.

Olsson IU. 1986. A study of errors in ${ }^{14} \mathrm{C}$ dates of peat and sediment. Radiocarbon 28(2A):429-35.

Olsson IU. 1991a. Accuracy and precision in sediment chronology. In: Smith JP, Appleby PG, Battarbee RW, Dearing JA, Flower R, Haworth EY, Oldfield F, O'Sullivan $\mathrm{PE}$, editors. Environmental history and palaeolimnology (Proceedings Vth International Symposium on Palaeolimnology, Cumbria, UK) Hydrobiologia 214:25-34

Olsson IU. 1991b. Submerged plants and the slow re- sponse to changes in radiocarbon activity of atmospheric carbon dioxide. Radiocarbon 33(2):227.

Olsson IU. 1993. A ten-year record of the different levels of the ${ }^{14} \mathrm{C}$ activities over Sweden and the Arctic. Tellus 45B:479-81.

Olsson IU. 1998. Reduction of the error multiplier by a long-term analysis of the characteristic behaviors of proportional counters. Radiocarbon 40(1):143-9.

Olsson IU. 1999. Geophysical aspects of problems in interpretations of Icelandic radiocarbon dates of archaeological samples. Norwegian Archaeological Review 32:95-110.

Olsson IU, El-Daoushy F, Vasari Y. 1983. Säynäjälampi and the difficulties inherent in the dating of sediments in a hard-water lake. Hydrobiologia 103:5-14.

Olsson IU, El-Gammal S, Göksu Y. 1969. Uppsala natural radiocarbon measurements IX. Radiocarbon 11(2):515-44.

Olsson IU, Florin M-B. 1980. Radiocarbon dating of dy and peat in the Getsjö area, Kolmården, Sweden, to determine the rational limit of Picea. Boreas 9:289305.

Olsson IU, Klasson M, Abd-El-Mageed A. 1972. Uppsala natural radiocarbon measurements XI. Radiocarbon 14(1):247-71.

Olsson IU, Possnert G. $1992 .{ }^{14} \mathrm{C}$ activity in different sections and chemical fractions of oak tree rings, $\mathrm{AD}$ 1938-1981. Radiocarbon 34(3):757-67.

Olsson IU, Vasari Y.1996. The long-term response of submerged plants in the hard-water lake, Säynäjälampi, to the bomb-radiocarbon injection. PACT 50:377-83.

Rajamäe R, Saarse L, Martma T, Heinsalu A, Poska A, Veski S. 1997. Carbon geochemistry in relation to sediment chronology of Lake Kahala. Proceedings Estonian Academy of Sciences, Geology 46:42-55.

Rajamäe R, Varvas M. 1990. Sedimentation in some NEEstonian lakes traced by ${ }^{210} \mathrm{~Pb}$ method. Freiberger Forschungshefte C 442:126-35.

Saarse L, Liiva A. 1995. Geology of the Äntu group of lakes. Proceedings Estonian Academy of Sciences, Geology 44:119-32.

Saarse L, Rajamäe R. 1997. Holocene vegetation and climatic change on the Haanja Heights, SE Estonia. Proceedings Estonian Academy of Sciences, Geology 46: 75-91.

Saarse L, Veski S, Heinsalu A, Rajamäe R, Martma T. 1995. Litho- and biostratigraphy of Lake Päidre, south Estonia. Proceedings Estonian Academy of Sciences, Geology 44:45-59.

Sand-Jensen K, Prahl C. 1982. Oxygen exchange with the lacunae and across leaves and roots of the submerged vascular macrophyte, Lobelia dortmanna $\mathrm{L}$. The New Phytologist 91:103-20.

Søndergaard M. Sand-Jensen K. 1979. Carbon uptake by leaves and roots of Littorella uniflora (L.) Aschers. Aquatic Botany 6:1-12. 
Steemann Nielsen E. 1946. Carbon sources in the photosynthesis of aquatic plants. Nature 158:594-6.

Stuiver M. 1975. Climate versus changes in ${ }^{13} \mathrm{C}$ content of the organic component of lake sediments during the Late Quaternary. Quaternary Research 5:251-62.

Stuiver M, Deevey ES. 1961. Yale natural radiocarbon measurementsVI. Radiocarbon 3:126-40.

Stuiver M, Deevey ES. 1962. Yale natural radiocarbon measurementsVII. Radiocarbon 4:250-62.
Westermark T. 1953. Åldersbestämning medelst radioaktivt kol enligt Libby. Elementa 36:85-100.

Wium-Andersen S. 1971. Photosynthetic uptake of free $\mathrm{CO}_{2}$ by the roots of Lobelia dortmanna. Physiologia Plantarum 25:245-8.

Wium-Andersen S, Andersen JM. 1972. Carbon dioxide content of the interstitial water in the sediment of Grane Langs $\varnothing$, a Danish Lobelia lake. Limnology and Oceanography 17:943-7. 